\title{
Exploring the potential of cuttlebone waste to produce building lime
}

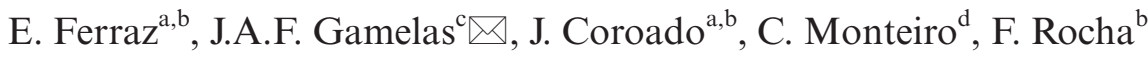 \\ a. Techn\&Art, Polytechnic Institute of Tomar, (Tomar, Portugal) \\ b. Geobiotec, Department of Geosciences, University of Aveiro, (Aveiro, Portugal) \\ c. CIEPQPF, Department of Chemical Engineering, University of Coimbra, (Coimbra, Portugal) \\ d. $\mathrm{CaCO}_{3}$ - Conservação do Património Artístico, (Tomar, Portugal). \\ $\triangle$ jafgas@eq.uc.pt
}

Received 19 November 2019

Accepted 25 March 2020

Available on line 17 July 2020

\begin{abstract}
The goal of this study is to find a practicable way to recycle cuttlebone waste in the production of lime. It was studied the behavior of calcium oxide obtained from the calcination of this waste at 900, 1000 and $1100{ }^{\circ} \mathrm{C}$ and, after wet slaking, the produced lime was characterized. All the results were compared to calcium oxide or to hydrated lime obtained from commercial limestone. According to the slaking results, the waste and the limestone calcined at $1000^{\circ} \mathrm{C}$ achieved the $\mathrm{R} 4$ (around $13 \mathrm{~min}$ to reach $60{ }^{\circ} \mathrm{C}$ ) and $\mathrm{R} 5\left(60{ }^{\circ} \mathrm{C}\right.$ in $25 \mathrm{~s}$ ) reactivity class, respectively. Changing the calcination temperature to 900 or $1100{ }^{\circ} \mathrm{C}$ did not promote an increase in the reactivity of the calcined waste. Although less reactive than the calcined limestone, the calcined cuttlebone can be transformed without significant constraint into building lime, since this construction material fulfills the relevant physic-chemical standard specifications.
\end{abstract}

KEYWORDS: Lime; Calcium carbonate; Waste treatment; Hydration; Characterization.

Citation/Citar como: Ferraz, E.; Gamelas, J.A.F.; Coroado, J.; Monteiro, C.; Rocha, F. (2020) Exploring the potential of cuttlebone waste to produce building lime. Mater. Construcc. 70 [339], e225 https://doi.org/10.3989/mc.2020.15819

RESUMEN: Explorando el potencial de los residuos de jibia en la producción de cal para construcción. El objetivo de este estudio es encontrar una forma práctica de reciclar los desechos de la jibia en la producción de cal. Se estudió el comportamiento del óxido de calcio obtenido de la calcinación de estos residuos a 900, 1000 y $1100^{\circ} \mathrm{C}$ $\mathrm{y}$, después del apagado húmedo, se caracterizó la cal producida. Todos los resultados se compararon con óxido de calcio o con cal hidratada obtenida de piedra caliza comercial. Según los resultados del apagado, los residuos y la piedra caliza calcinada a $1000^{\circ} \mathrm{C}$ alcanzaron la clase de reactividad $\mathrm{R} 4$ (alrededor de 13 minutos para alcanzar los $\left.60^{\circ} \mathrm{C}\right)$ y R $5\left(60^{\circ} \mathrm{C}\right.$ en $\left.25 \mathrm{~s}\right)$, respectivamente. Cambiar la temperatura de calcinación a 900 o $1100{ }^{\circ} \mathrm{C}$ no promovió un aumento en la reactividad de los residuos calcinados. Aunque son menos reactivos que la piedra caliza calcinada, la jibia calcinada puede transformarse sin restricciones significativas en cal para construcción, ya que este material de construcción cumple con las especificaciones físico-químicas estándar relevantes.

PALABRAS CLAVE: Cal; Carbonato cálcico; Tratamiento de residuos; Hidratación; Caracterización.

ORCID ID: E. Ferraz (https://orcid.org/0000-0003-4717-6305); J.A.F. Gamelas (https://

orcid.org/0000-0002-1474-767X); J. Coroado (https://orcid.org/0000-0001-6743-9278); C. Monteiro (https:// orcid.org/0000-0002-7141-9090); F. Rocha (https://orcid.org/0000-0002-3636-3933)

Copyright: (C) 2020 CSIC. This is an open-access article distributed under the terms of the Creative Commons Attribution 4.0 International (CC BY 4.0) License. 


\section{INTRODUCTION}

The calcium carbonate-rich shell, a biogenic excretion, secreted by some living organisms is a hard protection which makes part of the body of the animal. In general, the term seashell is correlated to the exoskeleton (external shell) of marine invertebrate animals, but in strict sense could be associated to both external or internal shells of marine molluscs. While most seashells are external, cephalopods of the Sepiidae and Spirulidae families have internal shells (endoskeleton) that function both as skeletal structure and as buoyancy device (1-2). The species of the Sepiidae family have a light, porous, brittle, oblong and fusiform shell, known as "cuttlebone" or "cuttlefish bone" that represents $\sim 9 \%$ of the volume of the animal (3) and the Spirulidae family presents species with hard coiled shell.

The cuttlebone consists of two different sectors: the upper part called the dorsal shield (or horny layer or hypostracum) and the lower part called the ventral chamber (or lamellar matrix or siphuncular) (4). The cuttlebone is a hollow material with a microscopic structure constituted by narrow layers, with quasi-periodic chambers, defined by horizontal lamellae (or septa) and upright pillars. The morphology and structure of the cuttlebone have been described in literature (4-6).

In the past, cuttlebone was ground up to make polishing powder used by goldsmiths, added to toothpaste, as anti-acid for medicinal purposes, as an absorbent or as an artistic carving medium. Traditionally, jewellers and silversmiths use it as moulds for casting small objects or in the process of pewter casting.

Nowadays, cuttlebone is commonly used as calcium-rich dietary supplement for pet animals (birds, reptiles, crabs, shrimps and snails). The design of biomimetic materials based on cuttlebone structure has been suggested (7). Cuttlebone powder has been studied as filler in gypsum plaster (8), in rubber (9) and in polyurethane (10). The possibility of producing calcium oxide from cuttlebone has also been explored (11). Calcined cuttlebone waste has been reported for several applications, such as, catalyst in biodiesel production $(12,13)$, biodiesel production through transesterification (14), $\mathrm{CO}_{2}$ sorbent (15), bone graft (16) and epoxy composites (17).

The cuttlebone is mostly composed of aragonite, an orthorhombic calcium carbonate polymorph, involved by $3.0-4.5 \mathrm{wt} \%$ of organic compounds (1). The microstructure has pore sizes in the range of $100-400 \mu \mathrm{m}$ and $\sim 93 \%$ of porosity (3).

Due to its value for human diet, cuttlefish species are worldwide captured and produced (aquaculture) with a global landing value around $440340 t$ for the year 2017 (18). Consequently, cuttlebone waste is generated in the large industrial food transformations plants, namely those related with clean frozen products.
Since cuttlebone is essentially composed of calcium carbonate, it has high potential, similarly to other carbonate-rich wastes (geologic or biogenic origin), to be used as raw material in the production of calcitic building lime. Building lime is defined, according to NP EN 459-1 standard (19), as a group of lime products, exclusively consisting of two families: air lime (calcitic or dolomitic) and lime with hydraulic properties, used in applications or materials for construction, building and civil engineering.

In this sense, it was studied the wet slaking behaviour of cuttlebone waste calcined at three distinct temperatures $\left(900,1000\right.$ and $\left.1100^{\circ} \mathrm{C}\right)$. The aim is to use this residue in the production of building lime. Recycling cuttlebone will transform this waste into an eco-binder construction product, fulfilling the principles of a circular economy, aligned with the concept of cleaner production.

\section{MATERIALS AND METHODS}

The cuttlebone waste, obtained from the European common cuttlefish (Sepia officinalis, Linnaeus, 1758), was collected from a local hypermarket in Portugal. Limestone, from an industrial rock plant, was used as reference material.

The waste $(\sim 950 \mathrm{~g})$, previously washed with tap water, and the commercial limestone $(\sim 900 \mathrm{~g})$ were dried at $105 \pm 5{ }^{\circ} \mathrm{C}$ (Memmert UF110), coarsely crushed in a porcelain mortar, milled in a tungsten grinder (Retsch RMO 100) for 3 min and sieved at $38 \mu \mathrm{m}$. The resultant powders were thoroughly characterized using X-ray diffraction (XRD), X-ray fluorescence (XRF) spectrometry, thermogravimetric analysis (TGA), differential scanning calorimetry (DSC), Fourier Transform Infrared - Attenuated Total Reflection (FTIR-ATR) spectroscopy, and Raman spectroscopy, following the flowchart previously reported (20).

XRD was performed on a Philips X'Pert PRO MPD diffractometer operating with $\mathrm{CuK} \alpha$ radiation at $50 \mathrm{kV}$ and $30 \mathrm{~mA}$. Diffractograms were recorded with a scan rate $0.02^{\circ} \mathrm{\theta} / \mathrm{s}$ in the range $4^{\circ}-65^{\circ} 2 \theta$. Crystalline phases were identified by comparison with the powder diffraction files from the International Centre for Diffraction Data. Chemical analysis of the major and minor elements by XRF was carried out using a PANalytical equipment PW 4400/40 Axios with $\mathrm{CrK} \alpha$ radiation. A pressed disc $(\approx 115 \mathrm{MPa})$ containing $6-10 \mathrm{~g}$ of powder and 4-5 drops of polyvinyl alcohol with about $4 \mathrm{~cm}$ diameter and $0.5 \mathrm{~cm}$ height was prepared for analysis. The loss on ignition (LOI) was determined gravimetrically, by calcinating the sample at $1000{ }^{\circ} \mathrm{C}$ for $3 \mathrm{~h}$ in ambient (oxidizing) atmosphere. TGA and DSC were performed simultaneously on a Netzsch Jupiter STA 449C apparatus, under oxidizing (air) atmosphere, between 20 and $1000{ }^{\circ} \mathrm{C}$ at a heating rate of $10{ }^{\circ} \mathrm{C} / \mathrm{min}$. FTIR spectra were 
recorded on a Bruker Alpha spectrometer in the $400-4000 \mathrm{~cm}^{-1}$ range using $4 \mathrm{~cm}^{-1}$ resolution and 128 scans. Raman spectra $\left(100-4000 \mathrm{~cm}^{-1}\right.$ range, $4 \mathrm{~cm}^{-1}$ resolution and 200 scans) were obtained in a Bruker RFS 100/S FT-Raman spectrometer, equipped with YAG:Nd laser (1064 $\mathrm{nm}$ and $350 \mathrm{~mW}$ excitation source).

The cuttlebone waste and the commercial limestone were calcined at $900{ }^{\circ} \mathrm{C}, 1000{ }^{\circ} \mathrm{C}$ and $1100{ }^{\circ} \mathrm{C}$ in a Nabertherm N 100/H laboratory kiln under air atmosphere $\left(3{ }^{\circ} \mathrm{C} / \mathrm{min}\right.$ of heating rate; $2 \mathrm{~h}$ of soak time). The calcined products were additionally milled in a porcelain roller ball mill during $15 \mathrm{~min}$, and sieved at $250 \mu \mathrm{m}$, for the wet slaking tests.

The specific surface area and the morphology of the calcined products were evaluated. The specific surface area was determined by $\mathrm{N}_{2}$ adsorption at $77 \mathrm{~K}$ in a Micromeritics ASAP 2000 instrument. Samples were previously treated in a vacuum at room temperature before analysis. The morphology was evaluated by field emission scanning electron microscopy (FESEM) in a Carl Zeiss Merlin microscope, in secondary electron mode. An acceleration voltage of $2 \mathrm{kV}$ and working distance of $6.6 \mathrm{~mm}$ were used and the samples were previously sputtercoated with gold (21).

The quicklime powders were submitted to the wet slaking reactivity test according to NP EN 459-2 standard (22). The wet slaking curve was calculated with the data of three replicates, considering a coefficient of variation in the reaction time below 10\%. The following parameters were obtained:

- t60, time (min) for a suspension of $\mathrm{CaO}(150 \mathrm{~g})$ and water $(600 \mathrm{~g})$ to reach $60{ }^{\circ} \mathrm{C}$;

- reactivity class, classification of the $\mathrm{CaO}$ reactivity according to the time ( $\mathrm{min}$ ) to reach $60^{\circ} \mathrm{C}$ : R5 class if less than 10 min or R 4 class if between 10 and $25 \mathrm{~min}$;

- T'maximum, maximum temperature $\left({ }^{\circ} \mathrm{C}\right)$ reached during the test;

- Tmaximum, maximum temperature $\left({ }^{\circ} \mathrm{C}\right)$ corrected for the water equivalent of the apparatus: Tmaximum $=(1.1 \times$ T'maximum $)-2$;

- Tu for $80 \%$ of the reaction, temperature $\left({ }^{\circ} \mathrm{C}\right)$ for $80 \%$ of the reaction, calculated as: $\mathrm{Tu}=(0.8 \times$ T'maximum $)+(0.2 \times \mathrm{T} 0)$, where $\mathrm{T} 0\left({ }^{\circ} \mathrm{C}\right)$ is the initial temperature of the water $\left(\sim 20^{\circ} \mathrm{C}\right)$;

- tu for $80 \%$ of the reaction, time ( $\mathrm{min}$ ) for $80 \%$ of the reaction, obtained by the wet curve.

The hydrated limes obtained after the slaking test (for calcination at $1000{ }^{\circ} \mathrm{C}$ ) were evaluated regarding their expansion behaviour, according to NP EN 459-2 standard (drying at $150 \pm 5{ }^{\circ} \mathrm{C}$, for $4 \mathrm{~h}$, under air atmosphere) (22). The powder samples were then analysed by XRD, XRF and FTIR-ATR, and CIE $\mathrm{L}^{*} \mathrm{a} * \mathrm{~b} *$ color measurements. The color was evaluated using a portable
Konica-Minolta CM-700d spectrophotometer, with the data of four replicates (20).

\section{RESULTS AND DISCUSSION}

\subsection{Cuttlebone waste}

Bulk XRD of the raw cuttlebone sample (Figure 1) indicates that the inorganic matrix is composed just by aragonite, in accordance with previously published data (2). Traces of halite were also detected, probably arisen from seawater. Commercial limestone was composed of calcite, with vestigial amounts of dolomite (20).

The chemical analysis by XRF (Table 1) shows the expected prevalence of $\mathrm{Ca}$ in both the raw materials. However, a slightly lower value was obtained for cuttlebone $(53.4 \mathrm{wt} \%)$ in comparison to limestone $(55.2 \mathrm{wt} \%)$. Additionally, some amount of $\mathrm{Na}$ $(0.8 \mathrm{wt} \%)$ was found in cuttlebone, which is related to presence of halite identified by XRD and other possible inorganic contaminants. Noticeable contents of $\mathrm{Sr}(0.3 \mathrm{wt} \%)$ and $\mathrm{Cl}(0.3 \mathrm{wt} \%)$ were also found in the cuttlebone, the latter element also associated to halite phase. Magnesium $(0.4 \mathrm{wt} \%)$ was found in the limestone due to the vestigial dolomite. The loss on ignition was slightly higher for cuttlebone $(44.5 \mathrm{wt} \%)$ than for the limestone $(43.9 \mathrm{wt} \%)$ sample. This reflects the different organic matter and calcium carbonate content of the two materials.

The weight loss in the thermogravimetric plot of cuttlebone (Table 2) occurs in three steps: one step $(1.0 \%)$ up to $\sim 110^{\circ} \mathrm{C}$ due to the release of adsorbed

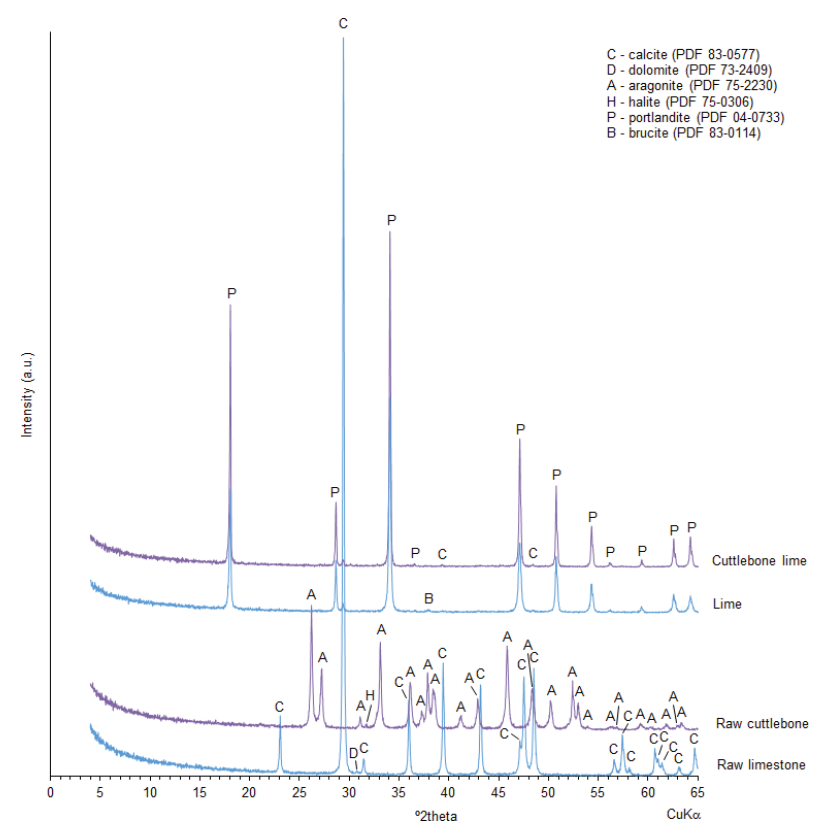

FIGURE 1. XRD patterns of the raw and lime materials from cuttlebone and limestone with the identification of phases. 
TABLE 1. XRF data (in wt $\%$ ) of the raw and lime materials from cuttlebone and limestone.

\begin{tabular}{lcccccccccccc}
\hline Sample & $\mathbf{C a O}$ & $\mathbf{M g O}$ & $\mathbf{N a}_{2} \mathbf{O}$ & $\mathbf{K}_{2} \mathbf{O}$ & $\mathbf{S i O}_{2}$ & $\mathbf{A l}_{2} \mathbf{O}_{3}$ & $\mathbf{F e}_{2} \mathbf{O}_{3}$ & $\mathbf{P}_{2} \mathbf{O}_{5}$ & $\mathbf{S O}_{3}$ & $\mathbf{S r}$ & $\mathbf{C l}$ & $\mathbf{L O I}^{\mathbf{a}}$ \\
\hline Raw limestone & 55.23 & 0.38 & 0.04 & 0.01 & 0.20 & 0.12 & 0.06 & 0.01 & 0.06 & 0.01 & $\mathrm{nd}^{\mathrm{b}}$ & 43.87 \\
Raw cuttlebone & 53.37 & 0.15 & 0.76 & 0.05 & 0.15 & 0.06 & 0.05 & 0.09 & 0.20 & 0.32 & 0.27 & 44.51 \\
Lime & 81.69 & 1.25 & 0.09 & 0.04 & 0.22 & 0.11 & 0.17 & 0.01 & 0.16 & 0.02 & 0.02 & 16.23 \\
Cuttlebone lime & 76.74 & 0.29 & 0.11 & $\mathrm{nd}^{\mathrm{b}}$ & 0.05 & 0.01 & 0.01 & 0.08 & 0.31 & 0.39 & 0.01 & 21.89 \\
\hline
\end{tabular}

$\mathrm{MnO}$ and $\mathrm{TiO}_{2}$ were also analysed in all the samples but not detected.

a LOI: loss on ignition

${ }^{\mathrm{b}}$ nd: not detected

TABLE 2. Thermogravimetric data for the raw cuttlebone and limestone samples.

\begin{tabular}{|c|c|c|c|c|c|}
\hline \multirow[b]{3}{*}{ Sample } & \multicolumn{4}{|c|}{ Weight loss (\%) } & \multirow{3}{*}{$\frac{\mathrm{CaCO}_{3}}{(\%)}$} \\
\hline & Moisture & Organic matter & & Total & \\
\hline & $20-110^{\circ} \mathrm{C}$ & $110-650{ }^{\circ} \mathrm{C}$ & $\mathrm{CO}_{2}$ & $20-1000^{\circ} \mathrm{C}$ & \\
\hline Raw limestone & 0.1 & 0.1 & $43.9\left[650-915^{\circ} \mathrm{C}\right]$ & 44.2 & 99.8 \\
\hline Raw cuttlebone & 1.0 & 3.6 & $40.8\left[650-860^{\circ} \mathrm{C}\right]$ & 46.1 & 92.8 \\
\hline
\end{tabular}

moisture; the second step $(3.6 \%)$ from $\sim 110{ }^{\circ} \mathrm{C}$ to $\sim 650{ }^{\circ} \mathrm{C}$ due to the degradation of organic matter, within the range reported (2); and, finally a third step $\left(40.8 \%\right.$ ), between $\sim 650{ }^{\circ} \mathrm{C}$ and $\sim 860{ }^{\circ} \mathrm{C}$ (Figure 2a) corresponding to the thermal degradation of calcium carbonate to calcium oxide. The theoretical calcium carbonate content was calculated to be $92.8 \%$. The presence in the DSC plot of an exothermic peak, at approximately $\sim 300{ }^{\circ} \mathrm{C}$ and of an endothermic peak, at around $\sim 825^{\circ} \mathrm{C}$ (Figure $2 \mathrm{~b}$ ), corroborate the results of the thermogravimetric analysis. Limestone shows the typical thermal behaviour expected for this material: one step of $43.9 \%$ weight loss (Figure 2a); and an exothermic peak at $\sim 855^{\circ} \mathrm{C}$ for the thermal degradation of calcium carbonate (Figure $2 b$ ).

Cuttlebone FTIR spectrum (Figure 3) shows the characteristic bands of aragonite: 1446 and $1462 \mathrm{~cm}^{-1}$ ( $\mathrm{v} 3$ - asymmetric stretching); $1083 \mathrm{~cm}^{-1}$ (v1 - symmetric stretching); $853 \mathrm{~cm}^{-1}$ ( $\mathrm{v} 2$ - outof-plane bending); 713 and $700 \mathrm{~cm}^{-1}(\mathrm{v} 4$ - in-plane bending). Additionally, a band of small intensity was observed at $1786 \mathrm{~cm}^{-1}$ probably due to a harmonic vibration $(v 1+v 4)$. A broad band at $1651 \mathrm{~cm}^{-1}$ was also observed which can be attributed to the $\mathrm{C}=\mathrm{O}$ stretching of the amide groups of chitin present in the raw cuttlebone (23). The limestone shows a FTIR spectrum as previously reported (20).

Finally, the Raman spectrum (Figure 4) of the cuttlebone exhibited vibrational bands at $1085 \mathrm{~cm}^{-1}$ (v1) and $703 \mathrm{~cm}^{-1}(\mathrm{v} 4)$ and translational bands at 285 , $271,259,248,205,180$ and $152 \mathrm{~cm}^{-1}$ which reveal the presence of aragonite, corroborating the results of XRD and FTIR. Two very small-intensity bands were additionally observed at $1573 \mathrm{~cm}^{-\mathrm{P}}$ (probably a combination band) and $1461 \mathrm{~cm}^{-1}$ (v3) (24).
The Raman spectrum of limestone was previously described (20).

\subsection{Calcium oxide from the calcination of cuttlebone waste}

The cuttlebone waste and the limestone sample were calcined at three temperatures: 900, 1000 and $1100{ }^{\circ} \mathrm{C}$, with $2 \mathrm{~h}$ soak time. Figure 5 presents the morphology of the obtained calcium oxide particles. The calcium oxide from limestone presented particles with irregular shape and rough and angular surfaces. The increase of the calcination temperature promoted a general agglomeration of the individual particles. This effect was more pronounced when the calcination temperature was increased from 1000 to $1100{ }^{\circ} \mathrm{C}$.

The size of the calcined particles of cuttlebone was markedly larger than the size of the calcined particles of limestone, as evident by the comparison of the SEM images of the calcined cuttlebone samples with those of the calcined limestone samples, with an ampliation ten times larger (d, e and $f$ versus a, b and c, in Figure 5). The calcium oxide from cuttlebone presented rounded crystals with smooth surfaces. The agglomeration of particles as well as the disappearance of pores seem to occur between $900{ }^{\circ} \mathrm{C}$ and $1000^{\circ} \mathrm{C}$, which could indicate a sintering stage. Minor morphological changes were observed between $1000^{\circ} \mathrm{C}$ and $1100^{\circ} \mathrm{C}$.

The BET specific surface area of the limestone calcium oxide samples decreased with increasing calcination temperature: $10.7 \mathrm{~m}^{2} / \mathrm{g}$ at $900{ }^{\circ} \mathrm{C}, 5.2 \mathrm{~m}^{2} / \mathrm{g}$ at $1000{ }^{\circ} \mathrm{C}$ and $2.3 \mathrm{~m}^{2} / \mathrm{g}$ at $1100{ }^{\circ} \mathrm{C}$. This agrees with the SEM microscopy results shown above, with smaller particles providing higher specific surface 
a)

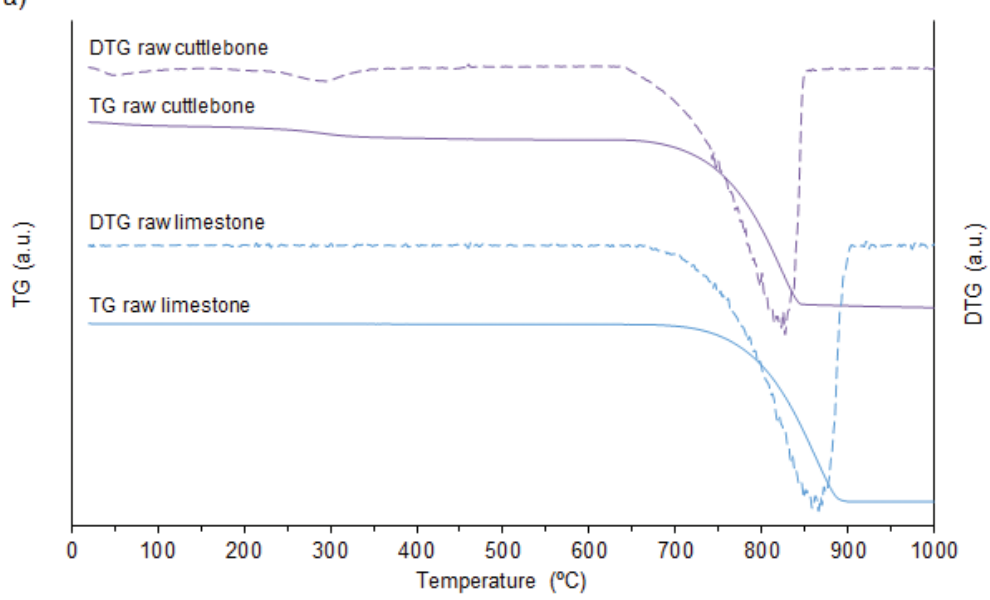

b)

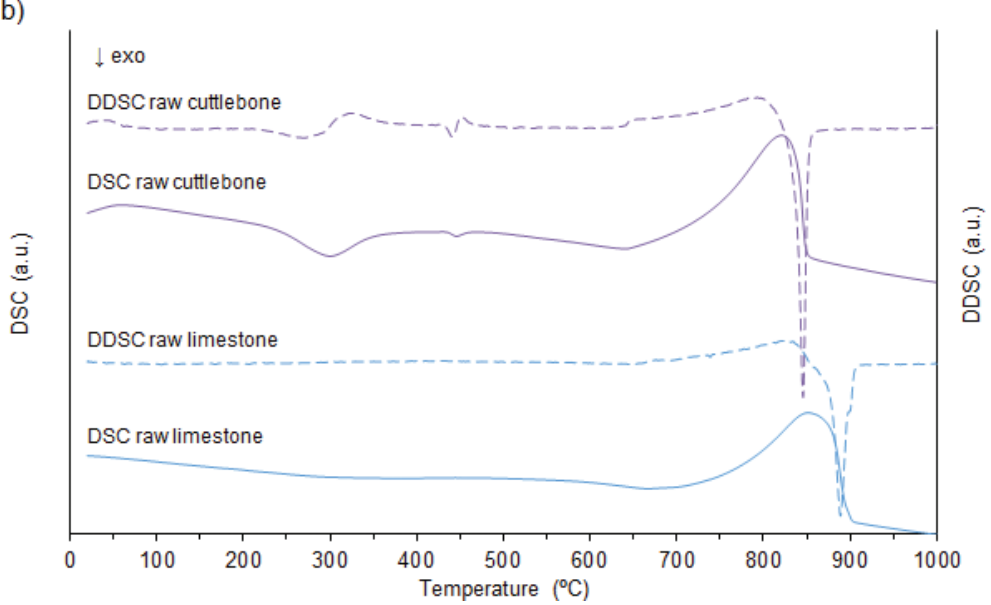

FIGURE 2. Thermal analysis results for the raw cuttlebone and limestone samples: a) Thermogravimetry (TG) plot and derivative curve (DTG); b) Differential scanning calorimetry (DSC) and derivative curve (DDSC).

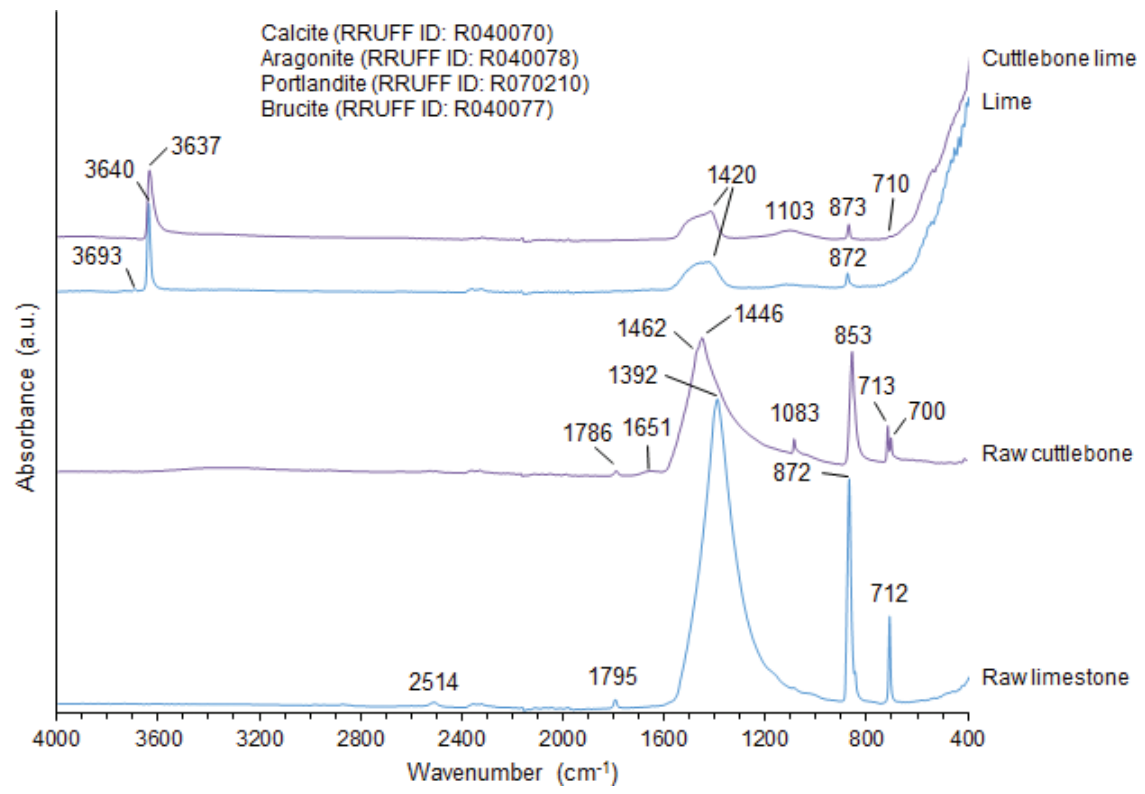

FIGURE 3. FTIR spectra of the raw and lime materials from cuttlebone and limestone. 


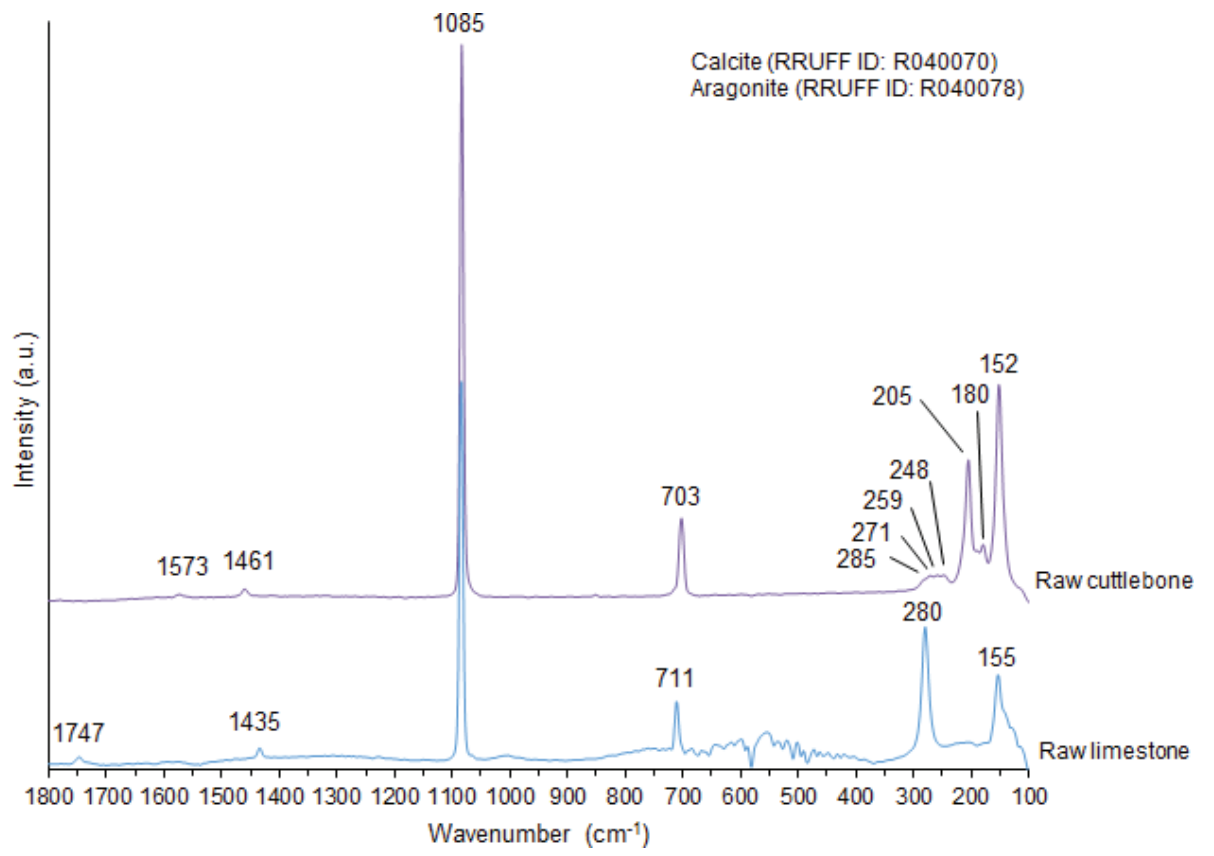

FIGURE 4. Raman spectra of the raw cuttlebone and limestone samples.

area. For the calcined cuttlebone, the magnitude of the BET values was lower: BET specific area was fifteen times lower at $900{ }^{\circ} \mathrm{C}\left(0.7 \mathrm{~m}^{2} / \mathrm{g}\right)$, five times lower at $1000{ }^{\circ} \mathrm{C}\left(1.0 \mathrm{~m}^{2} / \mathrm{g}\right)$ and two times lower at $1100{ }^{\circ} \mathrm{C}\left(1.1 \mathrm{~m}^{2} / \mathrm{g}\right)$. This is in agreement with the great particle size difference between the two materials, shown by SEM. The larger and more aggregated particles of calcium oxide from cuttlebone promote a lower specific surface area. However, it is noteworthy that when calcination temperature was increased to $1100{ }^{\circ} \mathrm{C}$, the BET values of both calcined materials approached each other. Again, this could be an evidence of the sintering stage.

Wet slaking tests were performed for the calcined cuttlebone samples and the calcined limestone. For the calcined limestone the temperature of $1000{ }^{\circ} \mathrm{C}$ was chosen, since this is the temperature usually used as reference in laboratory experiments. In the case of cuttlebone waste it was decided to change the calcination temperature, once for the tests with sample calcined at $1000^{\circ} \mathrm{C}$ the reactivity was not very high. Thus, temperature was increased and decreased of $100{ }^{\circ} \mathrm{C}$ relatively to the reference temperature. For the calcined limestone a remarkably high reactivity was already obtained for the calcination at $1000{ }^{\circ} \mathrm{C}$ (Figure 6), as expected (20).

The behavior of $\mathrm{CaO}$ from limestone was already described elsewhere (20). Briefly, this material is classified in the $\mathrm{R} 5$ class (reached $60^{\circ} \mathrm{C}$ in $25 \mathrm{~s}$ ). The calcium oxides from cuttlebone were much less reactive (the sample calcined at $1000^{\circ} \mathrm{C}$ reached $60{ }^{\circ} \mathrm{C}$ in 13:09 min:s). In agreement with the t60 values, the tu for $80 \%$ of the reaction was significantly longer for the calcined cuttlebone samples, showing that the hydration process is much slower. The values obtained in the reactivity test are in the same range of those obtained for razor and scallop seashells previously reported (20). The parameters T'maximum, Tmaximum and $\mathrm{Tu}, 80 \%$ reaction were similar for the calcined limestone $\left(1000{ }^{\circ} \mathrm{C}\right)$ and the calcined cuttlebone at $1000{ }^{\circ} \mathrm{C}$ and $1100{ }^{\circ} \mathrm{C}$ (Table 3).

Apparently, increasing calcination temperature from 1000 to $1100{ }^{\circ} \mathrm{C}$ for cuttlebone seems to slightly retard the hydration curve (Figure 6). In average, the values for $\mathrm{t} 60$ and $\mathrm{tu}, 80 \%$ reaction were approximately 1:30 min:s higher when using the cuttlebone waste calcined at $1100{ }^{\circ} \mathrm{C}$ (Table 3). However, a statistical analysis by ANOVA showed that the differences between the two tested temperatures are not significant: $F$ calculated $=1.16$ and $F 3 ; 3 ; 95 \%$ confidence level $=9.28 ; t$ calculated $=0.92$ and $t 6 ; 95 \%$ confidence level $=2.45$. These results indicate that changing the calcination temperature to $1100{ }^{\circ} \mathrm{C}$ does not promote an increase of reactivity in the wet slaking. Probably, the similar particle morphology and specific surface area (mentioned above) provide a similar wet reactivity, as well.

When calcining cuttlebone at $900{ }^{\circ} \mathrm{C}$ some difficulties were found in obtaining reproducible wet slaking curves. The referred temperature could be insufficient to achieve calcium oxide particles with homogeneous physicochemical properties. The temperature of $900{ }^{\circ} \mathrm{C}$ is also very close to the offset of $\mathrm{CaCO}_{3}$ degradation temperature $\left(\sim 860{ }^{\circ} \mathrm{C}\right)$ determined by thermogravimetry (Figure 2a). Notwithstanding, it was not observed a positive 

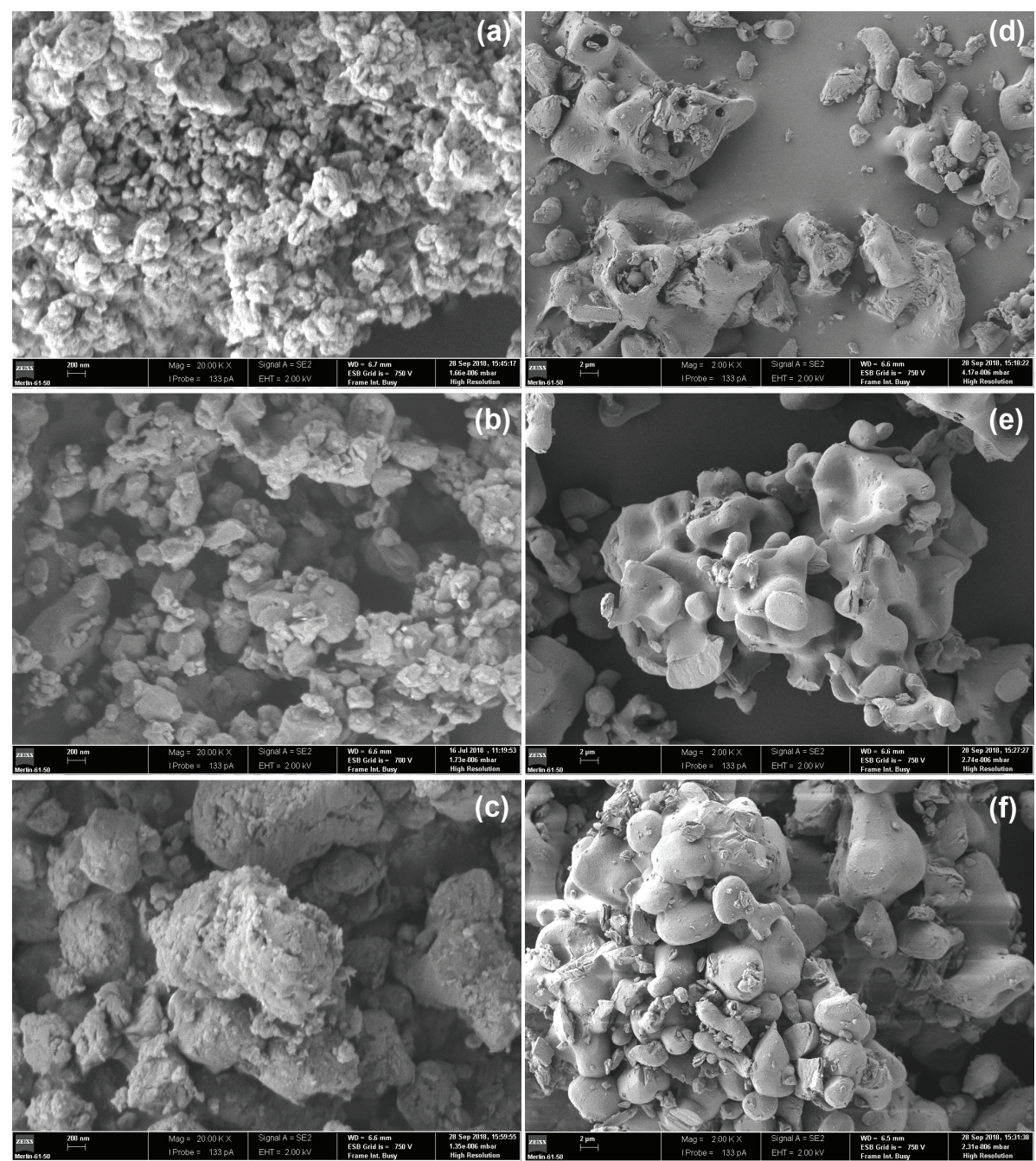

FIGURE 5. FESEM microphotographs of the calcium oxide particles obtained after calcination of: limestone (20000 magnification) at $900{ }^{\circ} \mathrm{C}(\mathrm{a}), 1000{ }^{\circ} \mathrm{C}(\mathrm{b})$ and $1100{ }^{\circ} \mathrm{C}(\mathrm{c})$; cuttlebone $\left(2000\right.$ magnification) at $900{ }^{\circ} \mathrm{C}(\mathrm{d}), 1000{ }^{\circ} \mathrm{C}(\mathrm{e})$ and $1100{ }^{\circ} \mathrm{C}(\mathrm{f})$.

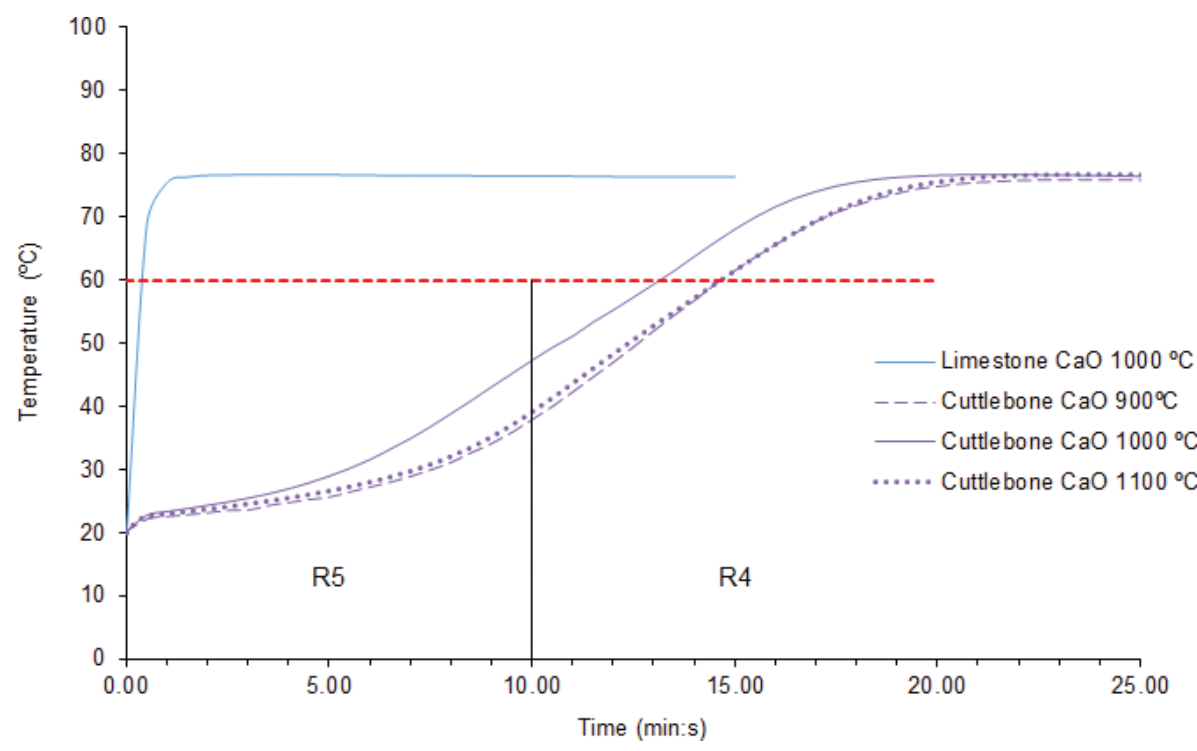

FIGURE 6. Wet slaking curves of the calcined cuttlebone and calcined limestone samples. 
TABLE 3. Wet slaking parameters for the calcined cuttlebone and calcined limestone samples.

\begin{tabular}{|c|c|c|c|c|c|c|c|}
\hline Sample & $\begin{array}{c}\text { Calcination } \\
\text { temperature }\left({ }^{\circ} \mathrm{C}\right)\end{array}$ & t60 (min:s) ${ }^{a}$ & $\begin{array}{c}\text { Reactivity } \\
\text { class }\end{array}$ & $\begin{array}{c}\text { T'maximum } \\
\left({ }^{\circ} \mathbf{C}\right)^{b}\end{array}$ & $\begin{array}{c}\text { Tmaximum } \\
\left({ }^{\circ} \mathbf{C}\right)^{\mathrm{c}}\end{array}$ & $\begin{array}{c}\mathrm{Tu}, 80 \% \\
\text { reaction }\left({ }^{\circ} \mathrm{C}\right)^{\mathrm{d}}\end{array}$ & $\begin{array}{l}\text { tu, } 80 \% \text { reaction } \\
(\text { min:s) })^{\mathrm{e}}\end{array}$ \\
\hline Limestone $\mathrm{CaO}$ & 1000 & $00: 25$ & R5 & 76.6 & 82.3 & 65.3 & 00:28 \\
\hline \multirow[t]{3}{*}{ Cuttlebone $\mathrm{CaO}$} & 900 & $14: 41$ & R4 & 75.9 & 81.5 & 64.7 & $15: 46$ \\
\hline & 1000 & 13:09 & $\mathrm{R} 4$ & 76.7 & 82.4 & 65.4 & $14: 22$ \\
\hline & 1100 & $14: 39$ & $\mathrm{R} 4$ & 76.7 & 82.4 & 65.4 & $15: 56$ \\
\hline
\end{tabular}

${ }^{a}$ t60 - time to reach $60{ }^{\circ} \mathrm{C}$

${ }^{\mathrm{b}}$ T'maximum - maximum temperature reached

${ }^{\mathrm{c}}$ Tmaximum - maximum temperature reached, corrected using Equation [1]:

Tmaximum $=(1.1 \times$ T'maximum $)-2 \quad[1]$

${ }^{\mathrm{d}} \mathrm{Tu}, 80 \%$ reaction - temperature for $80 \%$ of the reaction, calculated by Equation [2]:

$\mathrm{Tu}=\left(0.8 \times \mathrm{T}^{\prime}\right.$ maximum $)+(0.2 \times \mathrm{T} 0)$, where $\mathrm{T} 0\left({ }^{\circ} \mathrm{C}\right)$ is the initial temperature of the test $\left(\sim 20^{\circ} \mathrm{C}\right)$ [2]

${ }^{\mathrm{e}}$ tu, $80 \%$ reaction - time for $80 \%$ of the reaction, obtained by the wet curve

effect of changing the calcination temperature from 1000 to $900{ }^{\circ} \mathrm{C}$ in the overall reactivity. Instead, the average wet curve was retarded (Figure 6) and the corresponding t60 and tu, $80 \%$ reaction even seemed to increase in comparison to the sample calcined at $1000{ }^{\circ} \mathrm{C}$. The statistical comparison between the t60 results at 900 and $1000{ }^{\circ} \mathrm{C}$, however, provided a $F$ value of 0.86 and a $t$ value of 1.24 , from which it can be inferred that there are no statistically significant differences.

The lower reactivity of cuttlebone versus limestone must be related with their larger particles, lower specific surface area and more agglomerated structure, as it was evidenced by the SEM micrographs.

The slaking curve of the calcium oxide from cuttlebone exhibited a "S" pattern by opposition to a "line" pattern of the calcined limestone. The hydration rate of the calcined materials is influenced by the two induction periods underlying the slaking process. The slaking of the $\mathrm{CaO}$ from limestone is developed in one step, as previously reported (20), with no induction period. The hydration rate of the $\mathrm{CaO}$ from cuttlebone could be divided in three steps. As example, for the wet slaking curve of the $1000{ }^{\circ} \mathrm{C}$ calcined sample, the first up to $30 \mathrm{~s}$, the second from $30 \mathrm{~s}$ to 5:00 min:s, and the third one from 5:00 to 16:30 min:s, present a hydration rate of $5.1^{\circ} \mathrm{C} / \mathrm{min}, 1.3^{\circ} \mathrm{C} / \mathrm{min}$ and $4.0^{\circ} \mathrm{C} / \mathrm{min}$, respectively.

In the slaking of the calcium oxide samples it was not noted any relevant variation in the thickening of the suspensions.

\subsection{Lime from cuttlebone waste}

The lime suspensions were dried to obtain hydrated lime in powder form. For both materials, the characterization by XRD showed portlandite, as main phase, and vestigial contents of calcite. In the case of lime from limestone, traces of brucite were also detected, formed by the hydration of magnesium oxide present in the calcined material (Figure 1).

XRF data (Table 1) showed, as expected, calcium as major element $(81.7 \mathrm{wt} \%$ for lime from limestone and $76.7 \mathrm{wt} \%$ for lime from cuttlebone), obviously related with the presence of portlandite and calcite identified by XRD. The magnesium content was $1.2 \mathrm{wt} \%$ for lime from limestone, related with the brucite presence. The presence of strontium in the cuttlebone lime (already noted in the raw material) was confirmed. However, the sodium content as well as the chloride content were remarkably reduced after the calcination and the hydration, pointing out to solubilization during the hydration stage. The values of the loss on ignition were $16 \mathrm{wt} \%$ for lime from limestone and $22 \mathrm{wt} \%$ for lime from cuttlebone, related to the dihydroxylation of portlandite (and decarbonation of calcite).

Both FTIR spectra (Figure 3) of the limes showed the characteristic $\mathrm{O}-\mathrm{H}$ stretching band of the portlandite $\left(3637-3640 \mathrm{~cm}^{-1}\right)$. Bands of carbonate groups of calcite were also observed, including a broad band with maximum at $1420 \mathrm{~cm}^{-1}$ (v3). A weak and broad band at $1103 \mathrm{~cm}^{-1}$ was observed in the lime from cuttlebone, probably indicating the presence of sulfate ions (25), as was previously reported for limes obtained from waste seashells (20). A weak band at $3693 \mathrm{~cm}^{-1}$ (O-H stretching) due to brucite also occurred in the lime from limestone.

Finally, limes color properties were analyzed. The coordinates for the lime from limestone were $L^{*}=97.39, a^{*}=-0.02$ and $b^{*}=1.21$. For the lime from cuttlebone a slightly higher lightness (L coordinate) was obtained (98.22). The values for the coordinates $a^{*}(-0.16)$ and $b *(0.09)$, indicated a negligible shift to the green and to the yellow, respectively. The color results for the lime from cuttlebone, overall, point out to a white tonality material.

The hydrated lime powder from the waste material is in accomplishment with the specifications reported in the building lime standard. 
Final considerations should be paid to the incorporation of the cuttlebone waste in the process of building lime production at industrial scale. Although the quicklime from cuttlebone waste was less reactive than the quicklime from limestone, it is not expected that the mixture of cuttlebone waste and limestone would highly reduce the quality of the final produced lime, since the residue would always be incorporated in a small proportion relatively to limestone. This takes into account the lower amounts of available residue, in comparison to the quantities of limestone needed to feed a lime factory: a common Portuguese lime factory needs $\sim 1643$ t by day of limestone to reach an average daily production of $\sim 920$ t of quicklime (21). In Portugal, there are no cuttlefish-processing companies and consequently an industrial cuttlebone waste is not available. However, the Portuguese Statistical Institute indicates for instance, in 2018, an amount of $\sim 1030 \mathrm{t}$ for landing cuttlefish (26). Assuming that cuttlebone waste represents a maximum of $35 \%$ of the total mass caught (27), a value of 2360 t of this waste can be estimated for $2018(\sim 1 \mathrm{t} /$ day $)$. Therefore, it can be inferred that the referred scenario would allow the total consumption of the cuttlebone waste without predictable loss of the quality of lime. Recycling this type of waste in the production of an ecological binder material will also contribute to a more sustainable construction.

\section{CONCLUSIONS}

This work introduces a cleaner production practice of transforming cuttlebone waste into a building material for a sustainable construction, when compared with traditional process of lime production from limestone source. The raw material was composed by aragonite $(\sim 93 \mathrm{wt} \%)$, with halite as contaminating phase. Some amount of organic matter $(\sim 4$ $\mathrm{wt}^{\mathrm{0}} \%$ ) was also present.

The evaluation of the wet slaking behavior of the cuttlebone waste after calcination at several temperatures $\left(900,1000\right.$ and $\left.1100{ }^{\circ} \mathrm{C}\right)$ showed that it is possible to use it as a calcium carbonate source to produce building lime. However, the reactivity class was lower (R4) than that of calcium oxide from limestone (R5). There was not a significant effect of the calcination temperature on the wet slaking reactivity of the calcium oxide from cuttlebone. In fact, increasing temperature from 1000 to $1100{ }^{\circ} \mathrm{C}$ or decreasing temperature down to $900{ }^{\circ} \mathrm{C}$, even seemed to decrease slightly the reactivity, although not statistically significant. Overall, the calcination temperature of $1000{ }^{\circ} \mathrm{C}$ may be considered near the optimal one for the calcination of the waste material. The wet slaking curve of the cuttlebone waste had a "S" design, and the average time to reach $60{ }^{\circ} \mathrm{C}$ was 13:09 min:s for the waste sample calcined at $1000^{\circ} \mathrm{C}$.
The hydrated lime powder produced from the cuttlebone waste had a white tonality superior that of the lime produced from commercial limestone.

Using this waste in an industrial process of lime production enables its valorization in the construction industry, contributes to a sustainable exploitation of natural limestone, and, additionally, it represents an example of a circular economy application. In this way, the cuttlebone waste could partially replace, although in a small extent, the limestone commonly used in the process, while not significantly interfering with the restrictions and conditions underlying the industrial process of building lime production.

\section{ACKNOWLEDGMENTS}

The authors thank VAC Minerais, S.A. (Rio Maior, Portugal) for supplying the commercial limestone, the support of Quadro de Referência Estratégica Nacional (QREN) and R\&D units: Techn\&Art (UID/05488/2018) and Geobiotec (UID/GEO/04035/2019).

They also thank Prof. Dr. Francisco Franco Duro, from the University of Malaga (Spain), for the translations to Spanish language.

\section{REFERENCES}

1. Birchall, J.D.; Thomas, N.L. (1983) On the architecture and function of cuttlefish bone. J. Mater. Sci. 18, 2081-2086. https://doi.org/10.1007/BF00555001.

2. Sherrard, K.M. (2000) Cuttlebone morphology limits habitat depth in eleven species of Sepia (Cephalopoda: Sepiidae). Biol. Bull. 198 [3], 404 414. https://doi.org/10.2307/1542696.

3. Zhang, X.; Vecchio, K.S. (2013) Conversion of natural marine skeletons as scaffolds for bone tissue engineering. Front. Mater. Sci. 7, 103-117. https://doi.org/10.1007/ s11706-013-0204-x.

4. Le Pabic, C.; Rousseau, M.; Bonnaud-Ponticelli, L.; Von Boletzky, S. (2016) Overview of the shell development of the common cuttlefish Sepia officinalis during early-life stages. Vie Milieu - Life Environ. 66 [1], 35-42.

5. Čadež, V.; Škapin, S.D.; Leonardi, A.; Križaj, I.; Kazazić, S.; Salopek-Sondi, B.; Sondi, I. (2017) Formation and morphogenesis of a cuttlebone's aragonite biomineral structures for the common cuttlefish (Sepia officinalis) on the nanoscale: Revisited. J. Colloid Interface Sci. 508, 95-104. https://doi.org/10.1016/j.jcis.2017.08.028.

6. North, L.; Labonte, D.; Oyen, M.L.; Coleman, M.P.; Caliskan, H.B.; Johnston, R.E. (2017) Interrelated chemical-microstructural-nanomechanical variations in the structural units of the cuttlebone of Sepia officinalis. APL Mater. 5, 116103. https://doi.org/10.1063/1.4993202.

7. Cadman, J.; Zhou, S.; Chen, Y.; Li, Q. (2012) Cuttlebone: Characterisation, Application and Development of Biomimetic Materials. J. Bionic Eng. 9, 367-376. https:// doi.org/10.1016/S1672-6529(11)60132-7.

8. Sophia, M.; Sakthieswaran, N. (2019) Waste shell powders as valuable bio-filler in gypsum plaster - Efficient waste management technique by effective utilization. J. Cleaner Prod. 220, 74-86. https://doi.org/10.1016/j.jclepro.2019.02.119.

9. Poompradub, S.; Ikeda, Y.; Kokubo, Y.; Shiono, T. (2008) Cuttlebone as reinforcing filler for natural rubber. Eur. Polym. J. 44 [12], 4157-4164. https://doi.org/10.1016/j. eurpolymj.2008.09.015 
10. Shang, S.; Chiu, K.-L.; Yuen, M.C.W.; Jiang, S. (2014) The potential of cuttlebone as reinforced filler of polyurethane. Compos. Sci. Technol. 93, 17-22. https://doi.org/10.1016/j. compscitech.2013.12.019.

11. Soisuwan, S.; Phommachant, J.; Wisaijorn, W. Praserthdam, P. (2014) The characteristics of green calcium oxide derived from aquatic materials. Procedia Chem. 9, 53-61. https://doi.org/10.1016/j.proche.2014.05.007.

12. Sankaranarayanan, S.; Jindapon, W.; Ngamcharussrivichai, C. (2017) Valorization of biodiesel plant-derived products via preparation of solketal fatty esters over calcium-rich natural materials derived oxides. J. Taiwan Inst. Chem. Eng. 81, 57-64. https://doi.org/10.1016/j.jtice. 2017.10.007.

13. Catarino, M.; Ramos, M.; Dias, A.P.S.; Santos, M.T; Puna, J.F.; Gomes, J.F. (2017) Calcium Rich Food Wastes Based Catalysts for Biodiesel Production. Waste Biomass Valorization. 8, 1699-1707. https://doi.org/10.1007/ s12649-017-9988-8.

14. Ngamcharussrivichai, C.; Nunthasanti, P.; Tanachai, S.; Bunyakiat, K. (2010) Biodiesel production through transesterification over natural calciums. Fuel Process. Technol.91 [11], 1409-1415. https://doi.org/10.1016/j. fuproc.2010.05.014.

15. Castilho, S.; Kiennemann, A.; Pereira, M.F.C.; Dias, A.P.S. (2013) Sorbents for $\mathrm{CO}_{2}$ capture from biogenesis calcium wastes. Chem. Eng. J. 226, 146-153. https://doi. org/10.1016/j.cej.2013.04.017.

16. Dogan, E.; Okumus, Z. (2014) Cuttlebone used as a bone xenograft in bone healing. Vet. Med. 59, 254-260. https:// doi.org/10.17221/7519-vetmed.

17. Periasamy, K.; Mohankumar, G.C. (2016) Sea coral-derived cuttlebone reinforced epoxy composites: Characterization and tensile properties evaluation with mathematical models. J. Compos. Mater. 50 [6], 807-823. https://doi. org/10.1177/0021998315581512.
18. FAO - Global Production Statistics 1950-2017. Retreived from http://www.fao.org/fishery/statistics/global-production/query/en. Accessed 15 February 2020.

19. NP EN 459-1 (2015) Building lime. Part 1: Definitions, specifications and conformity criteria. Instituto Português da Qualidade, Caparica (in portuguese).

20. Ferraz, E.; Gamelas, J.A.F.; Coroado, J.; Monteiro, C.; Rocha, F. (2019) Recycling waste seashells to produce calcitic lime: characterization and wet slaking reactivity. Waste Biomass Valorization. 10, 2397-2414. https://doi. org/10.1007/s12649-018-0232-y.

21. Ferraz, E.; Gamelas, J.A.F.; Coroado, J.; Monteiro, C. Rocha, F. (2018) Eggshell waste to produce building lime: calcium oxide reactivity, industrial, environmental and economic implications. Mater. Struct. 51, 115. https://doi. org/10.1617/s11527-018-1243-7.

22. NP EN 459-2 (2011) Building lime. Part 2: Test methods. Instituto Português da Qualidade, Caparica (in portuguese).

23. Florek, M.; Fornal, E.; Gómez-Romero, P.; Zieba, E.; Paszkowicz, W.; Lekki, J.; Nowak, J.; Kuczumow, A. (2009) Complementary microstructural and chemical analyses of Sepia officinalis endoskeleton. Mat. Sci. Eng., C, 29 [4], 1220-1226. https://doi.org/10.1016/j.msec.2008.09.040.

24. Urmos, J.; Sharma, S.K.; Mackenzie, F.T. (1991) Characterization of some biogenic carbonates with Raman spectroscopy. Am. Mineral. 76, 641-646.

25. Bellamy, L.J. (1975) The infrared spectra of complex molecules, 3 ed. Chapman and Hall, London.

26. Estatística da Pesca 2018 (2019) Instituto Nacional de Estatística, Lisboa (in portuguese).

27. Balti, R.; Bougatef, A.; Ali, N.E.-H.; Zekri, D.; Barkia, A.; Nasri, M. (2010) Influence of degree of hydrolysis on functional properties and angiotensin I-converting enzymeinhibitory activity of protein hydrolysates from cuttlefish (Sepia officinalis) by-products. J. Sci. Food Agric. 90 [12], 2006-2014. https://doi.org/10.1002/jsfa.4045. 